\title{
AUGUSTE GAUVAIN I OTVARANJE JUGOSLOVENSKOG PITANJA NA POČETKU 20. STOLEĆA*
}

\begin{abstract}
APSTRAKT: Karijera i delo francuskog novinara, publiciste i u nekoliko navrata predstavnika Francuske u važnim međunarodnim misijama, urednika spoljnopolitičke rubrike liberalnog Journal des Débats, pisca važnih studija o evropskim $i$ balkanskim pitanjima vremena Treće republike - Ogista Govena, poslužila je za analizu šireg društvenog miljea u kome se formirala značajna grupa francuskih intelektualaca koja je bitno doprinela formulisanju i širenju tzv. jugoslovenskog pitanja. Analiza relevantnih tekstova O. Govena poslužila je da se vidi naučna, uopšte intelektualna podloga, a zatim i francuska i evropska, državna i diplomatska podloga oblikovanja jugoslovenskog pitanja.
\end{abstract}

Ključne reči: Ogist Goven, jugoslovensko pitanje, Francuska, Treća republika, Srbija, žurnalistika i politika.

\section{Ogist Goven i „francuski faktor“" u srpskoj i jugoslovenskoj istoriografiji}

Ogist Goven (Auguste Gauvain 1861-1931) polako ali sigurno ušao je u srpsku istoriografiju od kako ona postoji van jugoslovenskih kulturno-istorijskih okvira. U novim okolnostima, a možda baš zbog njih, učinjen je značajan napor da se sveobuhvatnije istraže događanja s preloma 19. u 20. stoleće koja su vodila ka jugoslovenskom ujedinjenju, a u kojima je Francuska odigrala najznačajniju ulogu. To je učinilo da se ime Ogista Govena počelo sve češće ponavljati, i to sa novim sadržajima. Jedan od ključnih zaključaka tih novih istraživanja je bio

* Rad je nastao u okviru projekta Tradicija i transformacija - istorijsko nasleđe i nacionalni identiteti u Srbiji u 20. veku, (№ 47019) koji finansira Ministarstvo prosvete i nauke Republike Srbije. 
da je Francusku i Srbiju na jugoslovenskom projektu spojila saglasnost njihovih nauka i kultura oko temeljnih spoznaja na kojima je taj projekat počivao. A najvažnije su bile spoznaje o jezičkoj istovetnosti i bliskosti, etničkoj srodnosti i bliskosti kulturno-istorijskog nasleđa jugoslovenskih zajednica, njihovoj verskoj razjedinjenosti i težnjama ka demokratskom organizovanju društva. Radilo se o bliskosti daleko većoj od vojnog savezništva koje je usledilo 1914-1918, od širenja zone investicija, političkog i vojnog uticaja. ${ }^{1}$

Ogist Goven je pripadao tom značajnom krugu francuskih delatnika, diplomata, državnika i političara, intelektualaca i naučnika, novinara i publicista koji su se bavili balkanskim i jugoslovenskim prostorom i bitno uticali na njegovo novo moderno organizovanje. Oni su Balkan videli i kao polje novih sloboda, i kao novu sferu uticaja. Teško je odrediti meru u kojoj je, u velikom zamahu uticaja francuske kulture i nauke u Evropi i na Balkanu, to bila težnja za širenjem ideja slobode, demokratije i modernosti, a koliko težnja za širenjem francuskog uticaja, za traženjem novih saveznika i nove strategije, u borbi sa nemačkim nacionalizmom koji je dominirao epohom 1871-1914, kao i epohom između dva svetska rata. $^{2}$

1 Milorad Ekmečić, „Više od vojnih saveznika 1914. (Prilog o francuskom izučavanju etničke prirode Jugoslovena)" u Ogledi iz istorije (drugo izdanje), Beograd, 2002, (prvo izdanje 1998), str. 191-219. Osnova teksta je referat na Međunarodnom naučnom skupu „Srbija i Francuska za vreme Prvog svetskog rata“, Istorijski institut SANU, Beograd, 15-16. septembar 1997. Objavljen je u nekoliko verzija i predstavlja prvi veliki prodor u istraživanju i interpretaciji srpsko-francuskih odnosa oko Velikog rata i stvaranja Jugoslavije, u potpuno izmenjenim okolnostima neprijateljstva i sukobljenosti između dva naroda. Tu se izlaže i tumači ideja o dubokoj saglasnosti srpske i francuske nauke i kulture, što je bilo mnogo više od vojnog savezništva 1914-1918, o najbitnijim osnovama jugoslovenskog projekta, kao što je etnička srodnost odnosno srodna etnička priroda Jugoslovena. Francuska i srpska nauka su do tih zaključaka došle nezavisno, pa su oni odatle, preko pojedinaca i nekih institucija, prešli u politiku i šire društveno mišljenje (antropogeografi Joseph Deniker i Eugène Pittard i Jovan Cvijić, zatim niz lingvista $s$ jedne i druge strane).

U tekstu se razmatraju i druge značajne ideje kao promena socijalnih osnova (u Francuskoj) na kojoj se stvaraju javna mnjenja, promena onih koji prenose znanja u oblikovanju javnog mnjenja (od leve inteligencije do profesionalnih slojeva u Francuskoj), smisao i značaj integrativnih i dezintegrativnih procesa na jugoslovenskom prostoru.

Andrej Mitrović, „Les intérets français à la veille de la Première Guerre mondiale“, La Serbie et la France: une alliance atypique. Relationes politiques; économiques et culturelles 1870-1940, Dušan T. Bataković (dir.), Belgrade, 2010, str. 231-251.

2 U novim evropskim i balkanskim okolnostima, francuska istoriografija proizvodi neobične revizionističke studije i monografije. Njima kao da želi više da ispravi nego objasni istoriju svog sukoba sa velikim evropskim konkurentskim nemačkim nacionalizmom, i svoju strategiju i prisustvo na Balkanu u toj epohi. Tu se ističe knjiga Grumel-Jacquignona, ali ima i drugih tekstova u tom pravcu.

Grumel-Jacquignon, François, La Yougoslavie dans la stratégie française de l'Entre-deux-Guerres (1918-1935). Aux origines du mythe serbe en France, Peter Lang Bern, XXV, str. 670.

(Komentar uz francusku bibl. jedinicu „Basé sur une analyse quasi exhaustive des archives françaises, cet ouvrage plonge au coeur des relations bilatérales franco-yougoslaves et illustre 
Istraživanje i predstavljanje Ogista Govena u našoj istoriografiji vodi nas direktno do na neki način novih velikih pitanja i sadržaja u kojima je on važna figura. Postavlja se pitanje zašto i pre razaranja Jugoslavije i sukoba Srba sa Evropom, pa i sa Francuskom, jugoslovenski projekat nije istraživan i kao međunarodni, evropski, pre svega francuski projekat, i na strani i kod nas. Zašto je tzv. francuski faktor kod nas zamagljivan istraživanjem uloge drugih savezničkih zemalja u jugoslovenskom ujedinjenju ${ }^{3}$ Zašto je toliko prenaglašavana uloga srpskog i ostalih jugoslovenskih nacionalizama u ujedinjenju kroz slabosti više carstava koja su se tom prilikom srušila? Da li je istraživanje tzv. francuskog faktora podrazumevalo da se odredi mera u kojoj je Evropa, i pre svega Francuska,

sur tous les plans (diplomatique, géopolitique, politique, idéologique, économique et culturel) l'intensité et la complexité des rapports entre Paris et Belgrade durant une période charnière qui voit se mettre en place les linéaments des crises yougoslaves de la fin du XXe siècle. Il y est démontré à tous les niveaux le poids de la première sur la seconde, à commencer par la création même du Royaume des Serbes-Croates-Slovènes en 1918 et la conception centralisatrice par la classe dirigeante serbe. Mais, malgré les atouts français, c'est sur un constat d'échec total que se conclut la tentative de la grande puissance qu'est alors la France d'utiliser le petit pion yougoslave; la cause essentielle en étant la différence fondamentale d'imaginaire géopolitique des Français et des Serbes. La force des mythes slavo-orthodoxes et balkaniques chez ces derniers annule en quelque sorte les atouts matériels des premiers. Ainsi, par delà le cas conjoncturel envisagé, c'est à une étude de l'un des déterminants fondamentaux des prises de décision en matière de relations internationales, trop souvent passé sous silence, qu'il est procédé ici.“)

O ovoj knjizi videti kritički prikaz: Mile Bjelajac, Notes de lecture u Balkanologie, Vol. VI, $n^{\circ} 1-2$, décembre 2002, p. 281-285. Grumel-Jacquignon (François), La Yougoslavie dans la stratégie française de l'entre-deux-guerres, aux origines du mythe serbe en France, Bern / Berlin / Bruxelles / Frankfurt / New York / Wien: Peter Lang, 1999, 669 p.

Dušan Bataković se takođe kritički osvrće na Grimel-Žakinjonovu knjigu u napomeni 14. svoje studije pod naslovom „Les relationes franco-serbes dans les récits des voyageurs français entre les deux guerres", u zborniku Les relationes Franco-Yougoslaves dans l'entre-deux guerres (1918-1940), Etudes Danubiennes, Tome XXIII, NUMEROS 1-2, Année 2007. Uz knjigu Mira Kovača (Francuska i hrvatsko pitanje 1914-1929, Dom i svijet - Zagreb 2005) on smešta i ovu knjigu u literaturu jasne prohrvatske orijentacije koja počiva na ograničenim izvorima i suženoj perspektivi, motivisana nacionalnim/nacionalističkim zahtevima.

Francuskom spoljnom politikom i strategijom Treće republike bavi se značajan broj knjiga, studija i članaka, iz za nas značajne perspektive, u zbornicima: Les relationes Franco-Yougoslaves dans l'entre-deux guerres (1918-1940), Etudes Danubiennes, Tome XXIII, NUMEROS 1-2, Année 2007. i La Serbie et la France : une alliance atypique : relations politiques; économiques et culturelles 1870-1940, Dušan T. Bataković (dir.), Belgrade 2010. Videti posebno tekstove Vojislava Pavlovića i Mileta Bjelajca. Citirani zbornici predstavljaju drugi značajan istraživački i naučni prodor u izmenjenim okolnostima sukobljenosti i neprijateljstva dva naroda i dve države.

3 Dragoljub R. Živojinović, Vatikan, Srbija i stvaranje jugoslovenske države 1914-1920, Nolit - Beograd, 1980; Isti, America, Italy and the Birth of Yugoslavia (1917-1919), East European Quarterly (distributed by Columbia University Press), New York, 1972, p. 338. Dragovan Šepić, Italija, Saveznici i jugoslovensko pitanje 1914-1918. godine, Zagreb, 1970. (Ovde treba uključiti radove Dragoslava Jankovića i Bogdana Krizmana). 
određivala ne samo opseg, odnosno granice nove države, ${ }^{4}$ nego i njeno mesto i ulogu u Evropi, njeno uređenje u funkciji tog mesta i uloge itd., a u kojoj meri sami jugoslovenski faktori, pre svega srpski? Da li je takvo istraživanje vodilo do pojedinaca u francuskoj nauci, kulturi, politici, diplomatiji i društvu, koji su kroz široko i detaljno proučavanje Balkana i jugoslovenskog prostora dali snažnu podršku njegovom modernom organizovanju na nacionalno-državnim jugoslovenskim osnovama, a koje je trebalo zaobići? Suženo i ideologizovano viđenje jugoslovenskog ujedinjenja nije samo dubinski zaobilazilo ulogu koju je u njemu odigrala Evropa, nego je ostavilo u mraku istorije izvrsne poznavaoce tzv. jugoslovenskog pitanja, jugoslovenskog pokreta, pa i čitave jugoslovenske istorije. Navođeni su oni, najčešće kao grupa, ponekad isticani pojedinačno, ali je sve to bilo više od blede senke njihovog ogromnog naučnog, novinarskog i publicističkog rada, političkog i društvenog angažmana, rada za državu i sl., koji su ugradili u stvaranje te države.

Sami kulturno-istorijski okviri jugoslovenskog zajedništva bitno su načeti razbijanjem jugoslovenske države, a time i istorijska nauka. Da li smo se time više udaljili ili, pojedinačno, približili Evropi? No, ne treba zanemariti istoriografsko nasleđe iz oba perioda Jugoslavije. Ako Kraljevina SHS/Jugoslavija nije uspela da podrobnije i ubedljivije sebe definiše i objasni i u istoriografiji, to je sigurno bilo bitno uslovljeno njenom stisnutošću u kratkom periodu između dva svetska rata. Ipak je međuratno vreme, u kome je Ogist Goven završavao svoju karijeru, dalo značajnih interpretacija jugoslovenske istorije kroz zajedništvo, kroz zajedničko postojanje i uzajamno prožimanje jugoslovenskih (ili južnoslovenskih zajednica, što je isto) zajednica na prostoru zapadnog Balkana. I te interpretacije su bile tumačene u potonjem vremenu. Bio je to izvestan nastavak sklada dve kulture, francuske i srpske, koji se preko tumačenja prošlosti (ljudi i prostora) pokušao proširiti na ostale jugoslovenske zajednice. ${ }^{5}$

Pre sloma Jugoslavije 90-ih godina prošlog veka, tzv. francuski faktor se prosto (zbog svog značaja i veličine) nije mogao izbeći u naporima srpske i jugoslovenske istoriografije u SFRJ da istraže i protumače sam čin jugoslovenskog ujedinjenja, ali i druga, dugotrajnija događanja/procese na zajedničkom prostoru. Istraživano je francusko prisustvo, percepcija i veze sa jugoslovenskim

Andrej Mitrović, Jugoslavija na Konferenciji mira 1919-1920, Zavod za izdavanje udžbenika SRS, Beograd, 1969.

5 Vladimir Ćorović, Istorija Jugoslavije, Narodno delo - Beograd, 1933. Isti, Odnosi između Srbije i Austrougarske u XX veku, Državna štamparija Kraljevine Jugoslavije, Beograd, 1936. (Nastojanjem Biblioteke grada Beograda ovo delo je ponovo štampano u Beogradu 1992, nažalost ne reprint izdanje). Isti, Istorija srpskog naroda I-III, (završeno 1941) Integralno elektronsko izdanje na www.rastko.rs/rastko-bl/istorija/corovic/index l.htlm. Istoriografski model koji je za pisanje francuske istorije uspostavio Charles Seignobos poslužio je kao uzor i za pisanje istorije Jugoslavije. Videti o tome M. Ekmečić, „Više od vojnih saveznika 1914. (Prilog o francuskom izučavanju etničke prirode Jugoslovena)" u Ogledi iz istorije (drugo izdanje), Beograd, 2002, (prvo izdanje 1998), str. 196, 197. 
prostorom od kraja 18. veka pa sve do sredine 20. veka. Pokušana je da se uspostavi, rekonstruiše osnovna crta francuskog prisustva na južnoslovenskom prostoru i celini Balkana pre svega u 19, ali i 20. veku. ${ }^{6}$

Osobenost i važnost onoga što nam je profesor Ekmečić dao kao svoju interpretaciju tzv. francuskog faktora stavljamo zasebno. ${ }^{7} \mathrm{Ne}$ samo zbog originalnosti viđenja i tumačenja, već pre svega zbog načina na koji je to urađeno. Razmatranje francuskog prisustva na Balkanu u modernoj epohi, vojnog i finansijsko-ekonomsko-privrednog, njegovog geostrateškog određivanja i percepcije tog prostora, istorije odnosa sa lokalnim zajednicama, idejnog i kuturnog uticaja, za profesora Ekmečića su deo šireg značaja koje su veliki evropski narodi i države imali na jugoslovenskom (ili južnoslovenskom) prostoru. Kako zbog njihovog direktnog prisustva, koje se u postkolonijalnom maniru vidi kao polukolonijalno, tako i zbog njihovog stalno prisutnog interesa, u obliku rivalstva i sukoba, koji su se stalno obnavljali na jugoslovenskom i srpskom prostoru. Profesor Ekmečić je u svoja kapitalna istraživanja ugradio dubinski istorijski sloj strane dominacije i uticaja na našem prostoru, posebno francuskog interesa i uticaja zato što je ovaj bio jedan od retkih koji je video prostor i ljude na njemu kroz srodnosti, istovetnosti, zajedništvo, kroz težnju za slobodom. U svom kapitalnom delu o istoriji jugoslovenskih nacionalizama, njihovoj uzajamnoj povezanosti i zavisnosti (Stvaranje Jugoslavije, 1-2, Prosveta - Beograd 1989), on je široko i sistematično za 19. i 20. vek, ispitivao i francusku percepciju prostora, izučavanje jezika $i$ kulture, širenje francuskog uticaja itd. Više od drugih prodro je u unutrašnji sadržaj francuske misli, njihovih diplomatskih izveštaja, naučne produkcije, putopisa i publicistike, što je za period Treće republike posebno dopunio studijom koju je nazvao prilogom o francuskom izučavanju etničke prirode Jugoslovena. Tu

6 Prva je o francusko-srpskim odnosima pisala Ljiljana Aleksić-Pejković u knjizi Odnosi Srbije sa Francuskom i Engleskom 1903-1914, Istorijski institut - Beograd, 1965, 961. Vuk Vinaver je u svojoj studiji Jugoslavija i Francuska između dva svetska rata (Da li je Jugoslavija bila francuski ,, satelit“?), ISI - Beograd, 1985. (482 strane) uradio izuzetno mnogo za to vreme, dao jednu odličnu hroniku bilateralnih odnosa Francuske i Jugoslavije, i širih diplomatskih odnosa u Evropi, krećući se oko svih važnih (i manje važnih) evropskih pitanja, u maniru logičkog pozitivizma, obradio niz posebnih pitanja u međusobnim odnosima dve države. Zatim je usledio zbornik radova (posle naučnog skupa koji je organizovao Istorijski institut u Beogrdu 1989) Jugoslovensko-francuski odnosi. Povodom 150 godina od otvaranja prvog francuskog konzulata u Srbiji (ur. Slavenko Terzić), Beograd, 1990, 415. Tu je prvi put postavljen i dat kontinuitet, makar kroz zasebne i ne direktno povezane tekstove, francusko-srpskog odnosno jugoslovenskog odnosa. (Ovde nije citirana relevantna literatura koja se odnosi na 19. vek, koja takođe nije brojna, i uključuje radove profesora Čedomira Popova).

7 М. Екмечић, Устанак у Босни: 1875-1878, Сарајево, 1960 (II изд. 1973, III. измењено изд., Београд - Службени лист СРЈ, Балканолошки институт САНУ, 1996, 428 стр; Исти, Ратни иильеви Србије 1914. године, Београд, 1973, 550. Исти, Историја Југославије (са Владимиром Дедијером, Иваном Божићем и Симом Ћирковићем), Просвета - Београд, 1972. (превод: History of Yugoslavia, Њујорк 1974). Исти, Стварағе Југославије 1790-1918, 1-2, Просвета - Београд, 1989, 662+842. Исти, Огледи из историје, Службени лист - Београд, 1999, стр. 498. 
su sva velika imena nauke, publicistike, novinarstva individualizovana kroz značajne sadržaje, misli i ideje iz njihovih tekstova, notiran je i njihov konkretan angažman na propagiranju srpskog i jugoslovenskog pitanja. Ogista Govena ostavlja za kraj citirajući čuvenu rečenicu iz uvoda studije o jugoslovenskom pitanju (La question Yougoslave, Paris 1918) kojom se on žalio da javnost ne razume Jugoslovene, „u očima zapadnih državnika Jugosloveni izgledaju kao uljezi. Za to je zaslužno samo njihovo ime. Ono u sebi sadži varvarsku atmosferu i prazno značenje." $" 8$

\section{Ogist Goven (1861-1931) : formiranje i karijera}

Najčešće ponavljana imena koja su se bavila isključivo jugoslovensko-balkanskim prostorom, ili i njime, bila su: Luj Ležer, Emil Piko, Ernest Deni, Emil Oman, Ogist Goven, Viktor Berar, Anri Loren, Šarl Loazo, Luj Ajzanman, Vikont Rober de Keks, Andre Šerdam, Maksim Šublije, Anri Barbi, Gaston Gravije, Pjer Kombre de Lani, A. kont de la Žonkijer. ${ }^{9}$ Oni su, kao pojedinci, bili deo istog društvenog miljea Treće republike na prelomu 19. u 20. stoleće. Tom krugu bi se mogla dodati i neka manje upadljiva imena, ali značajna za promišljanje i percepciju balkanskog prostora, kao što su Alber Sorel (18421906), Žak Ansel (1879-1943), Iv Šatenjo (1891-1969). Ali i neka velika imena nauke kao što su Žozef Deniker (1852-1918) i Ežen Pitar (1867-1962). ${ }^{10}$ Bilo

8 М. Екмечић, „Више од војних савезника 1914. (Прилог о франуском изучавању етничке природе Југословена)“, у Огледи из историје, Београд, друго издање, 2002, 221.

9 Louis Leger (1843-1923), Emile Picot (1844-1918), Ernest Denis (1849-1921), Emile Haumnt (1859-1942), Auguste Gauvain (1861-1931), Victor Berard (1864-1931), Henri Lorin (18661932), Charles Loiseau (1868-1946), Louis Eisenmann (1869-1937), Vicomte Robert De Caix (1869-1970), André Chéradame (1871-1948), Maxime-Max Choublier (1873-1933), Henry Barby (1876 - posle 1944), Gaston Gravier (1886-1915), Pierre Combret de Lanux (18871955), zatim A. comte de La Jonquière.

10 М. Екмечић, нав. дело. Značajan nastavak te unutrašnje analize sadržaja francuske misli o Srbima i Jugoslovenima dat je u studijama Dušana Batakovića „Les relationes franco-serbes dans les récits des vouageurs français entre les deux guerres" dans Les relationes Franco-Yougoslaves dans l'entre deux guerres (1918-1918), (Etudes Danubiennes, Tome XXIII, NUMEROS 1-2, Année 2007), p. 149-173. Značajne aspekte francuskog uticaja i prisustva u Srbiji i na Balkanu Bataković je dao u svojoj velikoj studiji „Le modèle français en Serbie avant 1914“ u zborniku radova La Serbie et la France : une Alliance atypique. Relationes politiques, économiques et culturelles 1870-1940, Académie Serbe des Sciences et des Arts, Institut des études balkaniques, éditions speciales 104, p. 13-101. S. Sretenović se u svojoj citiranoj monografiji o francusko-jugoslovenskim odnosima između dva svetska rata, gde se u Prvom delu pod naslovom Osnove francuske politike u Kraljevini Srba, Hrvata i Slovenaca (1878-1921) bavi zapravo periodom Treće republike, u kojoj su delovali navedeni pojedinci, pretežno bavi analizom njihove lične i društvene pozicije u događanjima vezanim za naš prostor, društvenim miljeom delovanja $i$ politikom u kojoj su učestvovali, a neznatno predstavljanjem njihovih ideja, stavova, kreativnim delom njihove uloge uopšte. Kao što je zaobišao neke važne autore koji su se sistematično i ozbiljno bavili istorijskim sadržajem o kome govori, kao što su Vuk Vinaver, Mile Bjelajac, Dušan Bataković, tako je zaobišao i profesora Ekmečića i njegove radove (Francuska i Kraljevina Srba, Hrvata i Slovenaca 1918-1929, Beograd, 2008). 
da su delovali u nauci kao istoričari-slavisti ili antropogeografi, ili u publicistici i novinarstvu, ujedno radeći raznovrsne poslove za državu (diplomatija, razne misije i sl.), svi su pokazivali jak sindrom onog najboljeg (kako se mislilo sa srpske strane) čime je zračio tzv. francuski duh epohe 1870-1914: privrženost idejama demokratije i laičkog društva, antigermanstvo i liberalni i slobodarski duh. Ako nisu bili među glavnim delatnicima velike škole metoda (école methodique), oni su sigurno bili njeni izdanci. ${ }^{11}$ Bez obzira na to šta je više uticalo na nastajanje i oblikovanje škole metode, tok istorije i istorijska stvarnost Francuske u 19. stoleću i posebno rivalstvo i sukob sa Nemačkom, ili težnje da se francuska pozitivistička škola odvoji od nemačkog uticaja, ili pak potreba da se baš zbog svega toga istorijska nauka usavrši teorijski i metodološki, može se reći da je sve to bilo snažan podsticaj za napredovanje slavističkih studija (jezika, književnosti, istorije, kulture, antropogeografije, političkih, društvenih i privredno-ekonomskih prilika, stanja ljudskih prava) i publicistike i žurnalistike okrenute ovom prostoru. Savez sklopljen sa Rusijom 1893. bio je izraz tih širih

R. W. Seton-Watson, „Louis Leger“ (Obituary), The Slavonic Review, Vol. 2, No. 5 (Dec., 1923), pp. 423-425. U prigodnom tekstu povodom smrti L. Legera, poznati slavista daje vrlo značajne i zanimljive detalje iz istorije slovenskih studija u Francuskoj, i posebno o ulozi poljske i mađarske emigracije od pre i iz 1848, koji su bitno uticali na mogućnosti razvoja i sistematičnog istraživanja Čeha, Slovaka, Južnih Slovena, Balkana. Tek su sitnije i krupnije političke promene posle 1867/68. (ujedinjenje Italije, poseta češkog političara Riegera Parizu i tajna audijencija kod Napoleona III) donele promenu prema tzv. manjim slovenskim narodima, i posebno u pravcu ozbiljnog i sistematičnog izučavanja prostora.

11 Isabel Noronha - Divanna, Writing History in the Third Republic, Cambridge Scholars Publishing, 2010, 295. (Official Book Description):

This book offers new insight to one of the most neglected periods of historiographical output: that of French historians between 1860 and 1914, a period often referred to as of positivistic historians or the ecole methodique. Having sought to assert their independence from Germanic influence by emphasising the French element in their work, historians in the period comprised between 1860 and 1914 sometimes described their approach as positivistic and maintained that this was a distinctively French method of studying history. This is a heightened concern with sources, with facts as basis for all true knowledge, and with truth itself were unifying elements of the historiography of those in the hiatus - in the gap - in what historians now call ecole methodique. Composed by Hippolyte Taine, Ernest Renan, Fustel de Coulanges, Gabriel Monod, Ernest Lavisse, Charles Victor Langlois and Charles Seignobos, this ecole represented the most sophisticated theoretical considerations about history and a method for historical studies in French academia in the late nineteenth century. To examine whether or not it is legitimate to call these historians methodiques for their concern with method and if they do, in fact, form a coherent school of thought is the purpose of this work. Likewise, it is my purpose to reassess whether or not this school is legitimately to be seen as having emerged in the Third Republic in response to political developments of nineteenth-century France, or if the so-called pre-methodiques and methodiques share more in terms of philosophy of history and methodology than previously emphasized by scholars. Finally, this book contributes to the debate surrounding the role of history and its method, offering a counter-argument to postmodernist scholars while reassessing the contribution of twentieth century theorists of history to the history of historiography. Amazon.com: Writing History in the Third Republic (9781443819343): Isabel Noronha-Divanna: Books 
intelektualnih i društvenih nastojanja, i obrnuto. Slovenski svet na jugoistoku, na Balkanu, Južni Sloveni, percipirani su i na tradicionalan način kroz tzv. istočno pitanje, istraživani su takođe i u krugu orijentalnih studija, ali su takođe posmatrani i kao deo celine slovenskog sveta kroz neoslavističku prizmu (gde su slovenski narodi ravnopravni za razliku od panslavizma 19. stoleća gde je dominantna Rusija među pravoslavnim Slovenima itd.). Dalje, jedan njihov deo je viđen kao deo Mittel Europe. Tu je francusku pažnju privukao njihov položaj, građanska i ljudska prava u Austrougarskoj monarhiji, naročito njihovo protestovanje i pružanje otpora pangermanskoj/velikonemačkoj struji u politici monarhije, ali i velikougarskim/velikomađarskim težnjama (koji ne mogu bez podrške germanske politike) i razbijanju mita o mađarskom liberalizmu u Evropi. Politički izraz boljeg viđenja i razumevanja, poznavanja samosvojnosti balkanskog prostora, gde su ljudi kao Ogist Goven odigrali glavnu ulogu, bilo je prihvatanje osnovnog stava demokratskog razrešenja istočnog pitanja: „Balkan balkanskim narodima“. Ključnu ulogu u francuskom formulisanju jugoslovenskog pitanja i razrađivanju celine jugoslovenskog projekta kroz saradnju pre svega sa Srbijom, ali i sa političkim snagama ostalih Jugoslovena, odigrala je već formirana, mada prihvaćena u uskim krugovima, spoznaja o jedinstvu i srodnosti prostora i ljudi na njemu kroz jezik, kulturu, pa i istoriju. Južnoslovenski prostor je bio jedan od onih čijim bavljenjem se modernizovala francuska nauka, publicistika i žurnalistika, diplomatija i politika, zato što je šire znanje stvaralo nove ideje, a one otvarale put za nova geostrateška, politička rešenja, za širenje polja sloboda. Polje gde se oprobavala jedna značajna, velika evropska sila, gde je oprobavala ideje i principe na kojima je počivala i ona i Evropa. Prostor na kome je pokušavala da suzbije nemački i proširi svoj uticaj preko realizovanja ideje „Balkan balkanskim narodima“, da smeni Osmansko carstvo na Balkanu i šire na Bliskom istoku, neutrališe ruski uticaj među pravoslavnim zajednicama Balkana, suzbije i neutrališe italijanski uticaj i na istočnoj obali Jadrana stvori dovoljno veliku južnoslovensku državu kao važan faktor evropske ravnoteže.

Ako do prelaza 19. u 20. stoleće, nekog vrhunca Treće republike, francuska slavistika i publicisti i novinari, diplomate i političari nisu postigli ozbiljnost, sistematičnost i sigurnost u bavljenju i spoznajama o balkanskom prostoru, to su sigurno postigle generacije koje su delovale kada i Ogist Goven, pored njega, uz njega, sa njim. ${ }^{12}$

Upotreba rezultata novih istraživanja, novih viđenja i razumevanja, bivala je sve češća u elitnim krugovima Treće republike. Tu su publicisti i novinari poput Ogista Govena odigrali ključnu ulogu. ${ }^{13}$ Ako je verovati samom Govenu

12 R. W. Seton-Watson, „Louis Leger“(Obituary), The Slavonic Review, Vol. 2, No. 5 (Dec., 1923), pp. 423-425.

13 Ogist Goven je bio novinar i urednik spoljnopolitičke rubrike u Journal des Débats 18891893. i 1908-192?, a Robert de Caix (vicomte) je radio u istom časopisu 26 godina, od 1893. 
najneprobojniji krug je bila francuska diplomatija, koja se teško odricala tradicionalnih koncepcija u spoljnoj politici. ${ }^{14} \mathrm{U}$ mnogo čemu poseban i originalan, Goven je bio duboko svestan koliko je bilo nepoznavanje jugoslovenskog prostora u Francuskoj i Evropi, koliko je teško i mučno prevazilaženje tog neznanja i predrasuda. $^{15}$

Ako nas je tada evropska kultura teško primala u svoje dvorište, u potonjem vremenu, okolnosti vezane za novu komunističku državu učinile su da za nas veliki i važni stranci ne postanu deo naše kulture i baštine, i kao takvi se vrate u svoje sredine. Mi sami smo sekli naše evropske veze i naše evropske korene. Krajnja posledica kratkovidih političkih odluka koje su sužavale prostor

do 1919. godine. Kao i Goven po Balkanu, obavio je više putovanja za državu po Aziji (18981909), bio generalni sekretar Francuskog visokog komesarijata/uprave u Siriji (1919-1925), od 1924. do 1939. bio je predstavnik Francuske u Mandatnoj komisiji u Ženevi. Bio je istaknuti predstavnik tzv. ,parti colonial““. Obim njegove delatnosti je bio ogroman. Kada se osniva časopis Le Monde Slave, kojim počinju da se naučno i politički artikulišu slovenska, a time i srpska pitanja, u prvom broju od 1. jula 1917. Robert de Caix sa Ernestom Denisom piše Notre Programme. (Videti o tome u M. Ekmečić, nav. delo, str. 195. i 210.) Goven se direktno i indirektno može povezati i sa drugim imenima iz grupe i šire, sa drugim pripadnicima elite koja se time bavila.

http://cosmos.ucc.ie/cs1064/jabowen/IPSC/php/authors.php?auid=46430, http://www.lesclesdumoyenorient.com/Robert-de-Caix-et-la-question-du.html .

14 A. Gauvain, La question yougoslave, Paris, Bossard, 1918. Isti, Les origines de la guerre européenne, Paris, A. Colin, 1915. V. Pavlović, „Une conception traditionaliste de la politique orientale de la France. Le viconte Joseph de Fontenay envoyé plénipotentiaire auprès du roi Pierre Ier Karageorgevitch (1917-1921)“, Guerres Mondiales et conflits contemporaines, 49 /193 (1999), p. 69-82. Naše je mišljenje da Fontenay nije imao tako tradicionalističku konepciju francuske orijentalne politike. Njegova percepcija i tumačenje Austrougarske monarhije je očevidno negativo i iz druge perspektive od one srednjoevropske. Ono koliko je tradicionalan mu omogućava da vidi bit državne konstrukcije kakva je bila Dvojna monarhija. Pravac u kom se kreću njegove analize i sugestije za francusku politiku na ovim prostorima je nov, i vremenom će prevazići i tradicionalan pogled na Habzburšku monarhiju i tzv. istočno pitanje, i to baš na jugoslovenskom pitanju.

15 Miodrag Ibrovac, „Auguste Gauvain“, Nova Evropa, knj. I, br. 2, 7. oktobar 1920, str. 68-70. K. J. Spasić citira, u navedenoj studiji, govore povodom smrti A. Govena, u ime SKA B. Gavrilovića, u ime BU Veselina Čajkanovića, u ime Udruženja rezervnih oficira i ratnika B. Bogića, sve preuzete iz Bratstvo, XXVI, 1932, str. 5-15, a zatim prenosi In memoriam iz Godišnjaka SKA, 40, 1931, str. 112-113.

Dušan T. Bataković, „Les relationes franco-serbes dans les récits des vouageurs français entre les deux guerres" dans Les relationes Franco-Yougoslaves dans l' entre deux guerres (19181918), (Etudes Danubiennes, Tome XXIII, NUMEROS 1-2, Année 2007), p. 149-173. Citat o Govenu je sa 151. str. i deo je prikaza njegove knjige koji se pojavio u La Patrie serbe i glasi: c'est lui - on peut affirmersans exagération - qui a fait le plus pour que le public français se familiarise avec l'idée de l'unité yougoslave et que la diplomatie de l'Entente ne se laisse pas entrainer a l'égard des Yougoslaves, sur le faux et dangereux chemin des marchandages politiques. Il nous a rendu triple service: d'abord il nous a fait connaitre en France et dans les pays alliés; ensuite il nous a défondus contre toutes les aspirationes imperialistes, d'ou qu'elles viennent; enfin, il nous a soutenus et encouragés dans notre pénible lutte, en nous créant des amis la ou nous n'en avions guère. (Objavljeno u: Mirko Hoppe dans La Patrie serbe, no. 10, Paris, Octobre 1918, p. 460) 
za istorijska istraživanja francuskog evropskog jugoslovenskog projekta je osiromašenje kulture na ovim prostorima, posebno srpskim. Takvi promašaji se nisu dogodili u drugim malim slovenskim narodima, kod Čeha, Slovaka, Bugara, kao ni kod drugih neslovenskih balkanskih zajednica. ${ }^{16}$

Ogist Goven je rođen u Vezulu (Vesoul), na istoku Francuske (Juras, Vogese) i pripadao je tzv. pograničnoj, sitnoj buržoaziji, opterećenoj antigermanskim sindromom, naročito od Francusko-pruskog rata 1870-1871. Obrazovan je na Ecole libre des sciences politiques. Kaže se da je završio prava. Zabeleženo je da 1888. nije uspeo na prijemnom ispitu Ministarstva spoljnih poslova za ulazak u diplomatsku službu. Počinje da radi za Journal des Débats, gde će izgraditi veliku karijeru. Generalni sekretar (Evropske) Dunavske komisije (Commission du Danube) u Galacu postao je 1893. i bio do 1903, a 1904. godine je imenovan za sekretara (frankofonskog) Centralne kancelarije za međunarodni transport (L'Office cental de transports internationaux) u Bernu. Vratio se u Journal des Débats 1908. i od tada bio glavni urednik spoljnopolitičke rubrike. Izabran je za člana L'Académie des sciences morales et politiques. U Beogradu je doživeo više počasti, postao je član Srpske kraljevske akademije i počasni građanin Beograda, rado viđen gost, a Paja Jovanović ga je (za akademske svrhe) ovekovečio portretom koji svedoči o delikatnoj prirodi. ${ }^{17}$

U Galacu, ondašnjoj i današnjoj velikoj luci na Dunavu, osamdeset kilometara udaljenoj od Crnog mora, sedištu Evropske dunavske komisije, osnovane posle Krimskog rata 1856, gde je boravio desetak godina, najverovatnije sa nekim prekidima, imao je prilike da sreće raznovrsno društvo, od konzula evropskih zemalja i SAD-a do rumunskih i ostalih političara sa Balkana. Galac je kao značajna dunavska luka i trgovačko-industrijski grad imao istorijski formiran raznolik etnički milje, bio na neki način Balkan u malome, i šire od toga, imao karakteristike lučkog grada. ${ }^{18}$

16 Osnovni pogled na prisustvo ovih velikih Francuza, u npr. Češkoj, pokazuje koliko njihova imena služe da obeleže trgove, ulice, hotele, koliko njihovih bista ima i gde su postavljene, uopšte gde, kako i sa kojom zamisli se njihova imena upotrebljavaju.

17 Auguste Gauvain - Wikipédia, Auguste Gauvain - Available Works, Le Petit parisien, 19. avril 1931. (necrologie) „Mort de M. Auguste Gauvain“. Krunoslav Spasić, „Srpska javnost o četvorici poznatih francuskih istoričara" $\mathrm{u}$ zborniku Jugoslovensko-francuski odnosi. Povodom 150 godina od otvaranja prvog francuskog konzulata u Srbiji (ur. Slavenko Terzić), Beograd, 1990. S. Sretenović, nav. delo, str. 36. i dalje. Prigodni tekstovi o Ogistu Govenu povodom izbora u Srpsku kraljevsku akademiju, za počasnog građanina Beograda, i nekrolozi i sećanja povodom smrti, objavljeni u Srpskom književnom glasniku i Novoj Evropi, koje citira Spasić, reprodukuju se i kod drugih autora koji govore o njemu ili ga spominju. Miroslav Timotijević, Paja Jovanović=Paul Joanowitch, Galerija SANU - Beograd, decembar 2009-januar 2010, (studijski tekst M. Timotijević, katalog Petar Popović), Beograd, 2010. Pod brojem 80. nalazi se Portret novinara Gavina, bez signature, SANU, Umetnička zbirka, (inv. br. 39).

18 Postoji građa o tome : http://gallica.bnf.fr/ark:/12148/bpt6k5453976h, http://www.foreignaffairs.com/articles/84684/anonymous/la-commission-europeenne-du-danube . 
Novinarsko-publicističku karijeru započetu 1889. prekinuo je 1903, ali je uspeo da sa Ernestom Levisom, jednim od najznačajnijih predstavnika škole metoda, objavi 1902. knjigu pod naslovom La vie politique à l'étranger (dir. E. Levisse, Paris 1892 , cca 550 p.).

Tokom rata dao je značajan doprinos u propagandi svih značajnih pitanja vezanih za manje slovenske narode, kako je on to govorio, ali i za druge balkanske narode, kao i za male ugnjetene narode uopšte (Jermene). Srbi i Jugosloveni koji su poznavali i pratili njegov rad smatrali su da je odigrao jednu od najznačajnijih uloga u propagiranju opšte jugoslovenske ideje. Zabeleženo je da je učestvovao u nekoliko značajnih aktivnosti i manifestacija za srpsko-jugoslovensku stvar. Sem njegove žurnalističke aktivnosti, radio je to u profesionalnoj i društvenoj komunikaciji. ${ }^{19}$

Kada se vratio novinarskom poslu, objavio je u 14 tomova sve svoje članke koje je objavio u Journal des Débats od 1908. do 1920. Posebno je, uglavnom tokom i u završnici rata, objavio seriju manjih i većih studija koje su ga učinile vrlo cenjenim u intelektualnim i diplomatskim krugovima Francuske i Evrope:

- Les origines de la guerre européenne, Paris, A. Colin, 1915.

- L'Europe avant la guerre, Paris, A. Colin, 1917.

- L'Affaire grecque, Paris, Bossard, 1917.

- La première guerre balkanique 1912, Paris, Bossard, 1918.

- La deuxième guerre balkanique 1913, Paris, Bossard, 1918.

- La question yougoslave, Paris, Bossard, 1918.

- L'Encerclement de l'Allemagne, Paris, Bossard, 1919.

- L'Europe au jour le jour, Paris 1920. (ima više novih izdanja, koja se uglavnom grupišu u 14 knjiga).

Balkanski prostor, i u njemu srpski i jugoslovenski, prisutni su u svim njegovim analizama složenih evropskih događanja. Na dubokom razumevanju te složenosti, kao i na razumevanju istorijske složenosti Evrope, on je formirao tzv. jugoslovensko pitanje. Može se reći da je upio principe i suštinu ,škole metoda“, iako bi njegov žurnalistički i istoriografski metod mogao da se veže i za logički pozitivizam. Za ova dva pravca u istoriografiji su vezana neka od najvećih imena evropske i svetske istoriografije i filozofije 20. veka, kao što su Alan. J. P. Tejlor i Bertran Rasel. Spominjemo Tejlora jer njegov princip kauzalnosti, odnosno uzročno-posledičnih veza više nego podseća na Ogista Govena. ${ }^{20}$

19 M. Ekmečić, nav. delo, str. 219.

D. Bataković, Les relation franco-serbes dans les récits ..., str. 151.

S. Sretenović, nav. delo, str. 36, 81, 256, 448.

V. Stanić, nav. delo, str. 482.

20 Zanimljivo da je Tejlor zastupao tzv. istorijski koncept koji je Treću republiku video kao dekadentnu državu, prevashodno misleći na Francusku u periodu između dva svetska rata. 


\section{Ogist Goven: jugoslovensko pitanje „iz dana u dan“}

U svom radu La question yougoslave (Paris, Bossard, 1918) Goven daje istoriju jugoslovenskog pitanja kroz veliki evropski rat 1914-1918. Tekst je komplementaran sa njegovim Les origines de la guerre européene (Paris, A. Collin, 1915). Proistekao je iz njegovog dnevnog praćenja evropskih događanja, na više ravni do one najdetaljnije, njegovog praćenja relevantne istoriografske literature (objavio je niz prikaza na istorijske knjige) i publicistike. Posebno je vidljivo praćenje nemačke, italijanske i anglosaksonske štampe i periodike, ruske takođe. Uz lično iskustvo stečeno boravkom i putovanjem po Balkanu, sve ovo čini njegov publicistički opus izuzetno relevantnim za istoriju jugoslovenskog pitanja, kako sadržajem iznesenih činjenica i podataka tako i analizama i zaključcima. Njegove činjenice, praćene i poređane u prirodnoj povezanosti, i dalje od toga u prirodno oformljenom uzročno-posledičnom nizu, nose snagu neposrednosti nastajanja, a njegove kopule i zaključci gotovo nepomerljivu snagu ubedljivosti. Njegova polazišta su jasna, i politički, i naučno, i intelektualno, i moralno, njegova glavna snaga je u kritičkom odnosu prema vlastitoj sredini, prema zapadnom viđenju i razumevanju prostora i zajednica koje ne smatraju delom svoje civilizacije. Kako je kritičan prema politici i prilikama u Francuskoj, i među savezničkim državama, tako je spreman da pozitivno oceni i podrži sve poteze koji dolaze iz sredina i država sa kojima Francuska nije bila u prijateljskim odnosima, posebno iz Nemačke.

Kritički odnos prema evropskoj percepciji balkanskog prostora (i u njemu srpskog i jugoslovenskog) i sa Zapada i sa Istoka i iz srednje Evrope, i iz perspektive Osmanskog carstva na uzmaku, hvale je vredno viđenje nezavidnog položaja naroda na njemu, dubokog neznanja i nerazumevanja kojim su oni bili obavijeni kao narodi bez vlastite istorije.

(The French Third Republic)

„Finally, Taylor has been criticised for promoting the La décadence view of the French Third Republic. This historical concept portrays the Third Republic as a decadent state, forever on the verge of collapse. In particular, advocates of the La décadence concept have asserted that interwar France was riven by political instability; possessed a leadership that was deeply divided, corrupt, incompetent and pusillanimous which ruled over a nation rent by mass unemployment, strikes, a sense of despair over the future, riots and a state of near-civil war between the Left and the Right. Of all the French governments of the interwar era, only the Popular Front government of Léon Blum was presented sympathetically by Taylor, which he praised for carrying out what he regarded as long overdue social reforms. Many experts in French history have admitted that there is a kernel of truth to Taylor's picture of France but have complained that Taylor presented French politics and society in such a manner as to border on caricature." http://en.wikipedia. org/wiki/A._J._P. Taylor .

Dray, William, „Concepts of Causation in A. J. P. Taylor's Account of the Origins of the Second World War", History and Theory, Volume 17, Issue \#1, 1978, p. 149-172. 
Goven kaže da je za većinu evropskog javnog mnjenja, posebno francuskog, jugoslovensko pitanje novo. Ono zbunjuje ljude za koje ne postoje druga sem pitanja katalogizovana u priručnicima iz istorije ili u zvaničnim arhivima. Ono pomalo razdražuje političare koji ne vole da budu uznemiravani u navikama svoga duha i koji smatraju kao veštačku tvorevinu pokrete i narode koje oni ne poznaju. Po njemu, Jugosloveni su državnicima na Zapadu poslednjih godina i meseci ličili na uljeze. Čak je i njihovo ime to zasluživalo, jer je u sebi sadržavalo varvarski prizvuk i nejasno značenje, veli Goven. Istini za volju, nastavlja, brojni su kultivisani zapadnjaci koji ne znaju da su to prosto Južni Sloveni, a oni među njima koji to znaju nemaju ništa sa čime bi to precizno uporedili. Ne zanima ih nimalo i teško se vezuju za pitanja naroda čiju istoriju ne znaju, koje teško smeštaju na mapama, koje primećuju samo kroz maglu. ${ }^{21}$

Odsustvo interesa za jugoslovensko pitanje kod sila Antante Goven smešta među najveće greške tokom ratnih godina. Naglašava da je propušteno da se uoči vrednost njihovih moralnih i materijalnih snaga i mogućnosti njihove upotrebe. Nisu uzimana u obzir ni njihova oglašavanja, protesti i sl., pa zaključuje da su čak i u demokratiji francuski ministri sačuvali stare navike velikih dvorova (des grandes Cours): više vole da razgovaraju sa predstavnicima velikih sila, a razgovorima sa šefovima ostalih misija se ne pridaje značaj. Tako se gube dragocene prilike da se obavesti o onome o čemu se nije učilo u mladosti i zanemaruje se mogućnost da se produbi znanje. Više se oslanja na obaveštenja iz druge i treće ruke, od agenata koji žele da im se dopadnu tako što će se uskladiti sa njihovim viđenjem koje se pretpostavlja, nego na direktne informacije kvalifikovanih stranaca koji poznaju do kraja zemlju i poslove o kojima su došli da razgovaraju. Naši političari se tako, veli Goven, pokazuju nesklonima prema ljudima koje drže za učesnike u razgovoru o bilo kom interesu koji se ne može uskladiti sa našim. Veli da se i kod Rusa rđavo razaznaje usklađenost, da ruski ministri i političari, premda Sloveni, ne razumevaju bolje jugoslovenske poslove od svojih zapadnih kolega. Zaključuje da su posledice ovakvih grešaka strašne kada se dođe do javnog pojašnjavanja pitanja kao što je jugoslovensko, a sve zato što je fatalnim spojem okolnosti ono izbilo u prvi plan. ${ }^{22}$

Austrougarska percepcija i iz nje proistekla antijugoslovenska propaganda detaljno se opisuju u pretposlednjem poglavlju studije pod naslovom Le mouvement yougoslave. ${ }^{23}$ Viđenje Jugoslovena kao subverzivnog, veleizdajničkog, kriminalnog elementa u svojim namerama i delima je porazno u svojoj ubedljivosti. Goven smatra da je Beč svojim klevetama uspeo da zatruje mnoge sredine, posebno u Vatikanu i Rimu. Kada se ovaj sublimni tekst o jugoslovenskom pitanju uporedi sa njegovim dnevnim analizama evropskih događanja, vidi

\footnotetext{
${ }^{21}$ A. Gauvain, La question ..., p. 5-6.

22 Isto, p. 7-8.

${ }^{23}$ Isto, p. 79-91, p. 82.
} 
se da je iza svakog iskaza, zaključka stajalo minuciozno, do u detalje, poznavanje svih elemenata događanja. ${ }^{24}$

Ponašanje Osmanskog carstva, odnosno Turske, naročito u periodu 1919-1923, Goven je posebno analizirao u studijama koje ovde nisu u direktnom razmatranju, a to su La première guerre balkanique 1912 i La deuxième guerre balkanique 1913, kao i u svojoj studiji pod naslovom Pet godina francuske politike na Bliskom Istoku koju je objavio u decembru 1924. ${ }^{25}$

U Jugoslovenskom pitanju on posebno razmatra pojedinačna ključna pitanja-probleme koji se odnose na svaku istorijski formiranu celinu koja je viđena kao sastavni deo buduće jugoslovenske države. I to kako pitanja vezana za njeno određenje prema spolja (pitanje granica i orijentacija u pogledu ekonomije, kulture...) tako i pitanja vezana za ponašanje njenih legitimnih predstavnika (odnosno vlasti) tokom rata. Bavi se i osnovnim opisom - skicom svake zajednice ponaosob. Tu se vidi da se više nego solidno uputio i u dublju istoriju svih jugoslovenskih administrativnih i državnih celina i zajednica, koje vidi i razumeva kroz zajedništvo i jedinstvo, ali uočava i posebnosti. Jasno je da je dobro iščitao istoriografiju škole metoda uopšte, posebno njene napore u spoznaji balkanskog prostora. Prihvatio je rezultate francuske, a ujedno i srpske, nauke o jedinstvu i srodnosti jezika i rase južnoslovrnskih zajednica. Kaže da se Jugosloveni dele na tri dela (Srbi, Hrvati, Slovenci) iste rase i gotovo identičnog jezika.

Za Srbe Goven kaže da su narod koji živi i izvan Srbije, u Crnoj Gori, Bosni, Hercegovini, u nekoliko županija jugoistočne Ugarske (Srem, tzv. Temišvarski Banat). Ne navodi da žive u Hrvatskoj, Slavoniji i Dalmaciji. Na Zapadu su najpoznatiji zbog svoje hrabre borbe i požrtvovanosti protiv Habzburške

24 Poređenje je pravljeno sa sadržajem studije Les origines de la guerre européene (Paris, A. Collin, 1915).

25 Tekst se može pročitati online u engl. prevodu na http://www.unz.org/Pub/HorneCharles1920v07-00218? View=PDF . Auguste Gauvain, „Five Years of French Policy in the Near East”, Foreign Affairs, dec. 1924, p. 218-226.

„The Turks have always owed their power to the dissensions of Christendom. Quarrels between the Greeks and Bulgars first opened the Balkan Peninsula to the Sultans. In 1453 Christianity allowed Constantinople to fall into the hands of Mahomet II. In the nineteenth century Anglo-Russian rivalry preserved the ruins of the Ottoman Empire. In the twentieth century, at the close of the World War, it was Anglo-French rivalry that allowed Turkey, guilty and defeated, exhausted and disheartened, to reestablish herself on both sides of the Straits and to set up her power anew in Constantinople, where, for the first time since the fall of Constantine Dragoses, there was a garrison of Christian troops. Baffled in their immense hopes, the old raias whom the armies of the West delivered from an oppression centuries old, have now suffered a fate more atrocious than after the greatest of the Osmanlis' victories. It is a fact unique in the annals of the civilized world that populations which were settled here for thousands of years before the Turks made their appearance in history have been driven out en masse by a treaty of peace to leave room for the Turkish invaders who pretend that this is their "homeland.“

How could such a thing occur? Who is responsible? A part of the responsibility does, indeed, weigh upon France--but a part only. Let us see how large a part.“ 
monarhije. Poredi ugled kralja Petra I i prestolonaslednika Aleksandra sa ugledom koji belgijski kralj i porodica imaju u Francuskoj.

Svakodnevni turski pritisak koji je tokom stoleća mrvio ceo Balkan i niziju srednjeg Podunavlja jedno vreme, Goven vidi kao „smrtnu tišinu“ nad jednim ogromnim prostorom koji je nekada bio prosperitetan. Ističe da Zapad do druge polovine 19. veka nije znao gotovo ništa o evropskim zemljama koje su sultani iz Konstantinopolja pokorili, a znanje koje su stekli poslednjih godina nije bilo dovoljno sadržajno ni tačno. Smatra da je to neznanje fatalno doprinelo da evropsko javno mnjenje i vlade velikih sila budu neusklađene tokom sukoba između Srbije i Bugarske oko Makedonije 1913. godine. Naglašavao je da je superiorna nemačka propaganda učinila da se zadugo veruje u legitimnost bugarskih zahteva nad jednom teritorijom nad kojom ona ,zasigurno“ nije imala više prava od Srbije. Stanovništvo te teritorije, uznemireno ratnim sukobima, bilo je spremno da se osloni na jednu ili drugu rivalsku državu u nadi da konačno dobije osnovne slobode. Satrvena 1913, Bugarska se revanširala 1915, kako kaže Goven. Konstatuje da Bugarska drži ,danas“ sporne makedonske teritorije i pretenduje da ih zadrži, kao i druge čisto srpske okupirane teritorije. Tu se vidi da je tekst pisan pre proboja Solunskog fronta u septembru 1918, da ni saveznici, a ni sama Srbija ne mogu biti pomirljivi kada je u pitanju srpski interes na ovim teritorijama. Po njemu Srbija ne bi mogla da opstane ni politički ni ekonomski bez celine Moravske doline. To joj priznaju i ostali Jugosloveni, pa će na tom pitanju biti jedinstveni blok na budućoj mirovnoj konferenciji. Koliko je Ogist Goven bio upućen u jugoslovenske razlike vidi se iz informacije da su po pitanju Stare Srbije po ugovoru iz Bukurešta mišljenja među Jugoslovenima bila podeljena. Sa retkom delikatnošću i finoćom on ističe da svi žele da se Srbija obnovi u obimu posle balkanskih ratova 1912-1913, ali da se neki pitaju ne bi li bilo prikladno da se zarad ostvarenja jugoslovenskog ujedinjenja žrtvuje jedan deo Makedonije kako bi se olakšalo opšte sređivanje prilika i trajni mir sa Bugarskom. Slovenci i Hrvati koji su okrenuti ka Jadranskom moru samo se dodatno interesuju za delove Balkana koji su okrenuti ka Egejskom moru i brine ih da Srbiju to ne zaokupi previše na uštrb zajedničkih interesa države koju žele da osnuju. ${ }^{26}$

26 O ovome videti detaljno kod M. Kovača, nav. delo, Drugi dio: Četvrto poglavlje, str. 83-125 (posebno nap. 115) i Peto poglavlje, str. 124-163. Takođe videti citirane radove D. Živojinovića, D. Šepića i A. Mitrovića. Problem neke vrste trgovine sa okupiranim teritorijama Kraljevine Srbije se provlačio u odnosima nekih predstavnika Jugoslovena iz Habzburške monarhije u Jugoslovenskom odboru i srpske vlade i političara, preko Francuza, istaknutih francuskih političara i državnika, izgleda od 1916, pa sve tokom Konferencije mira 1919-1920. do njenog kraja. Posebno je Trumbićeva „dvolična diplomatija“ izazvala nepoverenje kod Klemansoa. Emile Haumant o tome detaljno piše u La formation de la Yougoslavie (Paris, Bossard, 1930), p. 683-684. Goven je to sve sigurno znao, ali je mudro čuvao formu i stil u formulacijama. 
Mudro je zaključivao da Srbi, podučeni okrutnim iskušenjima i sa izgrađenim osećajem odgovornosti, ne žele da se odreknu pristupa Egejskom moru. Uvereni su, kaže Goven, da za normalan život i razvoj srpska država mora da ima slobodan pristup Egejskom moru, bilo da se svede na sopstvenu državu, bilo da se ugradi u veliku jugoslovensku državu. Samo tako Srbija može biti slobodna prema državama severno od Dunava i Drave. Ističe da izlaz na Jadransko more, bilo direktan srpski ili indirektan preko prijateljskih teritorija, ne daje iste garancije Srbiji. Na kraju zaključuje da je Jadransko more jedan veliki zaliv čiji se ulaz lako može zatvoriti. Ponovo se vraća na Prvi i Drugi balkanski rat 1912-1913. i objašnjava zašto se Srbija grčevito borila da osvoji i sačuva direktnu granicu sa Grčkom, odnosno zonom Soluna i donjeg dela Vardara, i zašto je Bugarska iz suprotnih razloga pretendovala da prisvoji Monastir, Ohrid i jednu stranu Albanije do Jadranskog mora. Radeći za sebe i Austro-Ugarsku, objašnjava Goven, ona je želela da odvoji Srbiju od Grčke i postane gospodaricom komunikacija preko makedonske teritorije. Da bi zadovoljila svoju ambiciju nije uzmicala pred najodvratnijom izdajom. Zbog svega ovoga je smatrao da Slovenci i Hrvati ne treba da budu ravnodušni prema mogućem potpuno zavisničkom položaju Srbije, odnosno nužnosti da ponovo uzme „slobodu kretanja do obala Egejskog mora“, ako tako čvrsto vezuju svoju sudbinu za sudbinu Srbije. Tu se radi i o njihovoj vlastitoj nezavisnosti, pa mu se činilo da su to neki među jugoslovenskim političarima počeli da razumevaju. ${ }^{27}$

Crnu Goru Goven smatra potpuno srpskom zemljom. Vidi da je dinastija Petrović-Njegoš politički jedina prepreka ujedinjenju dve države i da je narod masovno za ujedinjenje. Odlično poznaje odnose dveju dinastija i njihov zajednički rad na oslobođenju Srba u Habzburškoj monarhiji i Osmanskoj carevini tokom 19. veka i precizno ih skicira. Posebno je iscrtao ponašanje Nikole I Petrovića Njegoša u drugoj polovini njegove vladavine kada se počeo „otuđivati““ od Srbije. Vrlo je kritičan prema ponašanju crnogorskog kralja tokom rata, pa i crnogorske vojske. Ceni da su se ponašali ,više neutralno nego kao saveznici““.28 Poznaje precizno sve razmirice i sukobe crnogorskih ministara i kralja. Crnu Goru odvojenu od Srbije i jugoslovenskog okruženja, u nekoj nezavisnoj državi, Goven vidi kao početak agonije, najrđaviju moguću posledicu rata. I ovde je vidljivo da on uvek procenjuje gde je ko bio tokom rata, na kojoj strani, kako se ponašao i šta je radio, i vojno i politički i lično i društveno, o čemu je brinuo, koliko je žrtvovao.

Bošnjake i Hercegovce, kako ih naziva, vidi kao pripadnike jedne rase i jezika koje naziva srpsko-hrvatskim. Vidi njihovu podeljenost, daje precizne podatke o zastupljenosti pojedinih religioznih zajednica, o prirodi austrougarske vlasti, o tome kako se ko ponašao pod tom vlašću. Njenu suštinu vidi u politici

27 A. Gauvain, nav. delo, poglavlje pod naslovom Les Serbes de Serbie, do 15. str.

28 Isto, poglavlje pod naslovom Les Montenegrins, p. 15-25, posebno p. 18. 
divide et impera, koja se ogleda u sistemu favorizovanja, u prvom redu doseljenika katolika, pa muslimana, pa autohtonih katolika. Pravoslavno stanovništvo je habzburška vlast gledala kao velikosrpsko. Najvažnija mesta su zauzimali Nemci i Mađari, a policijom dirigovano iz Beča i Pešte. Na kraju Goven zaključuje da je monarhija, koja je želela da ograniči nezavisnost Srbije na svaki mogući način zato što ju je smatrala žarištem jugoslovenstva, dobila žarište u vlastitoj pokrajini kojom je vladala surovo diktatorski. Svi atentatori u tzv. Kraljevini Hrvatskoj i Dalmaciji i Bosni i Hercegovini bili su podanici te iste monarhije, poentira on na kraju. $^{29}$

Ističe da muslimani Bosne i Hercegovine nisu Turci, kako se to vrlo često veruje na Zapadu, nego Srbi. Priklanja se Ležeovoj interpretaciji porekla bogumilstva u srednjovekovnoj Bosni i Hercegovini, ${ }^{30}$ koju su u prošlosti sa Istoka doneli vojnici Vizantijskog carstva i koja je u vreme osmanskog osvajanja bila u velikom usponu. Proganjanje hrvatsko-ugarskih vladara ubrzalo je njihovo prelaženje u veru osvajača, koja im je bila bliska u svojoj jednostavnosti zbog gnosticizma, masalijanizma i manihejstva. Ne poznaje istoriju prelaženja sa pravoslavlja i katoličanstva na islam.

I na primeru Srba iz Ugarske se vidi koliko je Goven dobro poznavao istoriju svih srpskih i jugoslovenskih zajednica, koju skicira kroz seobe preko Save i Dunava i kroz ponovno potpadanje pod osmansku vlast tokom 15, 16. i 17. veka. Dobro poznaje i istoriju srpskih zajednica na ovom prostoru u 19. veku, njihov značaj (ekonomski, strateški) i posebno sve uspone i padove srpsko-hrvatske saradnje tokom ključnih događanja epohe. Uočava stagnaciju i opadanje položaja i srpskih i hrvatskih zajednica u monarhiji pod naletima agrarne kolonizacije i jezičke i kulturne mađarizacije na prostorima Južne Ugarske i Slavonije. Kao glavne probleme na južnougarskom prostoru, u sklopu jugoslovenskog pitanja, vidi razgraničenje sa Mađarskom zbog visokog stepena izmešanosti različitih etničkih zajednica i razgraničenje sa Rumunijom, zbog njenih velikorumunskih zahteva u čvrstim prirodnim granicama koje su išle do Tise. Uočava popuštanje rumunske vlade i nada se podeli Banata između dve države na prijateljski način. ${ }^{31}$

Najviše prostora u svojoj studiji La question yougoslave (p. 35-55) Goven daje Dalmaciji, čiju istoriju takođe dobro poznaje, citira Emila Omona ( $L a$ slavisation de la Dalmatie, Paris 1917), jugoslovenske autore (L. Vojnović, M. Čemerikić) i italijanske. Zapaža da su Dalmacija, Kvarner i Istra najugroženije jugoslovenske teritorije $\mathrm{i}$ da će ih biti izuzetno teško odbraniti. Daje precizne podatke o slovenskom etničkom sastavu, detaljno razmatra geostrategiju prosto-

29 Isto, poglavlje pod naslovom Les Bosniaques et les Herzegoviniens, p. 25-30.

30 Louis Leger, L'Histoire des Bogumiles en Bosnie et en Bulgarie au Moyen age, Paris.

31 A. Gauvain, La question yougoslave..., poglavlje Les Serbes de Hongrie, p. 29-35.

O razgraničenju sa Rumunijom videti studiju A. Mitrovića, Razgraničenje sa Rumunijom i Bugarskom... 
ra. Precizno skicira italijansku politiku, njene mane, takođe i promene u javnom mnjenju. Glavni argument zašto taj prostor treba da pripadne budućoj jugoslovenskoj državi, sem osnovnih kao što su rasa i jezik, jeste geostrateški i to onaj koji ide u prilog stvaranju jugoslovenske države. Istočna jadranska obala, precizno dalmatinska, neodbranjiva je za državu koja ne poseduje njeno zaleđe, a to zaleđe bi zahtevalo prisustvo vojske od više stotina hiljada ljudi da bi se ozbiljno čuvalo i branilo. Postoji rizik da bude u svakom trenutku odsečeno dolaskom neke vojske sa istoka, austrijske ako ona preživi, ili mađarske ako ojača, ili jugoslovenske ako se stvori (p. 49). Nemoguće je postići apsolutnu sigurnost na Jadranu za kojom žude Italijani.

Pitanje Hrvatske, u sklopu jugoslovenskog pitanja, razmatrano je na znalački i pronicljiv način. Autoru je bilo poznato sve do detalja, i dalja i bliža prošlost i duboka povezanost geografijom tla, rasom i jezikom sa drugim jugoslovenskim teritorijama. Pitanje hrvatske nezavisnosti je bilo duboko povezano sa pitanjem opstanka monarhije uopšte i posebno u njenoj dualnoj formi. S druge strane stajala je Italija, opterećena teškim antihrvatskim sindromom koji se istorijski taložio, i u ratnim godinama izvojevanim Londonskim ugovorom, potpuno nesklona svim varijantama jugoslovenskog ujedinjenja koje su uključivale Hrvatsku. U Rimu su cenili, veli Goven, da bi bilo najmudrije da ona ostane svojim starim gospodarima. On uočava kako su se italijanske simpatije za Srbiju počele umanjivati uznemiravajućom brzinom od kada su politički krugovi u Beogradu prigrlili jugoslovensku ideju. Ruska diplomatija, rđavo obaveštena i preokupirana idejom da izbegne religioznu kontaminaciju pravoslavnih Slovena od strane katoličkih, oslonila se na ove italijanske ideje, što je u proleće 1915. dovelo do ,klauzule o vetu“. Vlade u Parizu i Londonu su tada pokazale slabost da se vežu za politiku suprotnu pravu naroda da odlučuju o sebi samima. Ta klauzula je zabranjivala ujedinjenje Hrvata sa Srbima. Sa velikom preciznošću Goven prati sudbinu ove klauzule tokom rata i posebno 1918, kao i nove nagoveštaje $\mathrm{u}$ italijanskoj politici. Italijani su postajali skloni da pregovaraju o opozivu ove kaluzule o vetu na srpsko-hrvatsko ujedinjenje, ali da ovi za uzvrat priznaju ostale odredbe ugovora iz 1915. godine. Zato je Nikola Pašić tokom tih događanja kao mantru ponavljao da se Jugoslavija stvara ne samo protivno neprijateljima nego uprkos i prijateljima, možda baš zbog odsustva Rusije sa Balkana. ${ }^{32}$

Goven je izuzetno upućen i precizan i kada je u pitanju slovenačka istorija, gde analizira postignuća i kvalitete jedne male zajednice (visok procenat pismenosti, širenje zadrugarstva...), ali strateški važne jer u sklopu jedinstvene Jugoslavije zatvara pristup germanskom prisustvu na Jadranskom moru, i uopšte ,zaokruživanju Nemačke“", čime se bavi u studiji pod tim naslovom. ${ }^{33}$ Slovence inače vidi kao narod koji je tvorio prepreku ,germanskoj invaziji“

32 A. Gauvain, nav. delo, p. 55-71.

33 A. Gauvain, L'Encerclement de l'Allemagne, Paris, Bossard, 1919. 
na jug monarhije, koji ima svest o velikoj ulozi koju je obavljao sa zavidnom energičnošću, bez da bude zaveden ili zbunjen u tome. Zbog te velike zasluge za mediteransku civilizaciju, oni su po Govenu zaslužili da budu ujedinjeni sa ostalin Jugoslovenima u jednu i jedinstvenu državu.

U završnim poglavljima o jugoslovenskom pokretu i programu Goven daje posebnu analizu uloge liberalnog katoličkog sveštenstva u odbrani nacionalnih prava i teritorija, posebno slovenačkog, istarskog, kvarnerskog i sa ostrva, poimenice opisujući njihovu politiku i ponašanje uoči i tokom rata, kao i širenje kruga pristalica jugoslovenskog ujedinjenja unutar Katoličke crkve.

Sve te jugoslovenske snage ne vidi kao vulgarne propagatore ideje, ideološke ili revolucionarne zaluđenike, već kao ozbiljne ljude koji su jugoslovenstvo videli ili osećali kao svoje najdublje određenje, dublje od političkog ili ideološkog.

\section{Summary}

Dr Gordana Krivokapić-Jović

\section{Auguste Gauvain and the Opening of the Yugoslav Question at the Beginning of the $20^{\text {th }}$ Century}

Key words: Auguste Gauvain, Yugoslav question, France, Third Republic, Serbia, journalism, politics

Augiste Gauvain, a French journalist and publicist, French representative in international institutions and missions, a productive journalist and author-publicist whose journalist texts were written on daily basis, in detail and well founded about more or less all more important European questions, especially Balkan matters, filled some twenty volumes with his articles. He devoted a number of special studies to Balkan questions, the most important being The First Balkan War, The Second Balkan War, The Greek Question, The Yugoslav Questi$o n$. He remained a gray spot in Serbian and other Yugoslav historiographies until the break-up of Yugoslavia, having been mentioned only couple of times. However, since new relations of conflict, enmity and misunderstanding developed between Serbia and France, a significant breakthrough was made in the research of the French factor in the Yugoslav project, that started to be researched as an international, European project. In connection with that, Augiste Gauvain was researched too. The first important breakthrough was made by Professor Milorad Ekmečić in his study of the French research of ethnic nature of the Yugoslavs. Professor Ekmečić studied important, often decisive foreign factors in the creation of the Yugoslav idea and in military-political, social and economic shaping of 
the Yugoslav area, and the Serbian area within it. In the above mentioned study he researched mutual influences and links between science and politics in the French and Serbian social environment, as well as the harmony between the two sciences and cultures, and even politics, based on the unity and kinship of the Yugoslav area and the people inhabiting it. Another important breakthrough was made by Professor Dušan Bataković with two collections of papers on French-Serbian-Yugoslav relations during the $19^{\text {th }}$ and $20^{\text {th }}$ centuries in that he as editor and author opened many questions and topics, including the professional and ideological work of Augiste Gauvain. Gauvain's activity was successfully dealt with also in the study of Stanislav Sretenović who examined rather the social environment of the individuals who dealt with us within it, than the contents of their perceptions of the Balkans, analyzing diplomatic and military activities in French-Yugoslav relations.

With their rich contents and dynamics Gauvain's career and work served us to examine some of the most important elements of the new, modern view of the Balkan, Yugoslav and Serbian area in the most important period of its reorganization at the turn of the $20^{\text {th }}$ century and during the Great War of 19141918. The basis of his views on the Yugoslav question, that was very complicated due to intermingled presence and interests in the Balkans, created the ideas for which the Third Republic fought, the ideas of liberal, democratic and secular society, permeated with struggle for human and civic rights, new theoretical and methodological concepts in historical science. 